\title{
Arran pitchstone (Scottish volcanic glass): New dating evidence
}

\author{
Torben Bjarke Ballin
}

1. Lithic Research, Stirlingshire, UK. Email: lithicresearch@btinternet.com;

2. Honorary Research Fellow, University of Bradford, UK.

\begin{abstract}
:
In the present paper, the author offers new absolute and contextual dating evidence for Scottish archaeological pitchstone. Much archaeological pitchstone from the Scottish mainland is recovered from unsealed contexts of multi-period or palimpsest sites, and pitchstone artefacts from radiocarbondated pits therefore provide important dating evidence for this material group and its associated exchange network. In Scotland, all archaeological pitchstone derives from outcrops on the Isle of Arran, in the Firth of Clyde, and on the source island pitchstone-bearing assemblages include diagnostic types from the Mesolithic, Neolithic and Early Bronze Age period. Off Arran, pitchstonebearing assemblages never include Mesolithic types, such as microliths, suggesting a post Mesolithic date. This suggestion is supported by worked pitchstone from radiocarbon-dated pits, where all presently available dates indicate that, on the Scottish mainland, Arran pitchstone was traded and used after the Mesolithic period, and in particular during the Early Neolithic period.
\end{abstract}

Keywords: pitchstone, volcanic glass, Neolithic, radiocarbon dating, contextual dating, pits, prehistoric exchange

\section{Introduction}

In 2009, the author concluded the project Archaeological Pitchstone in Northern Britain with the publication of a monograph in which he discussed various issues relating to this topic (Ballin 2009a). The main reason for undertaking the project was the fact that the number of artefacts in this raw material, as well as the number of pitchstone-bearing sites, had multiplied exponentially. When Williams Thorpe \& Thorpe (1984) published their important paper on the topic, only approximately 1,400 pieces of worked pitchstone were known, from c. 100 find locations, but in 2009 approximately 20,300 pieces had been recorded, from $c$. 350 sites. The aim of the present paper is to present new absolute and contextual dating evidence for Scottish archaeological pitchstone.

Before proceeding any further, it may be relevant to first explain to readers based outside Scotland what pitchstone is. Basically, pitchstone is a very close 'relative' of obsidian.

Published by the School of History, Classics and Archaeology, University of Edinburgh ISSN: 2055-0472. URL: http://journals.ed.ac.uk/lithicstudies/

This work is licensed under a Creative Commons Attribution 2.5 UK: Scotland License. 
Obsidian and pitchstone are both defined as being forms of acid volcanic glass, but first and foremost by containing more or less water. In Ballin \& Faithfull $(2009,5)$, the authors wrote:

Pitchstone is glassy, usually silica-rich, igneous rock with a characteristic lustre resembling that of broken pitch. Pitchstones are generally held to be hydrated equivalents of obsidians, although the usage of both terms [...] has often been imprecise (cf Pellant 1992).

The International Union of Geological Sciences has recently published a comprehensive nomenclature scheme for these and other igneous rocks (Le Maitre 2002). Here, the term pitchstone is restricted to hydrated glassy rocks (typically $3-10 \% \mathrm{H}^{2} \mathrm{O}$ ), while obsidians are nearly anhydrous $(<$ $1 \% \mathrm{H}^{2} \mathrm{O}$ ). Most pitchstones have $>5 \% \mathrm{H}^{2} \mathrm{O}$, and most obsidians $<0.5 \%$.

Some definitions suggest that obsidian is pure whereas pitchstone contains crystalline inclusions, but this statement is so overly general that it must be characterized as less than helpful. Some rare obsidians (low water content) contain phenocrysts, spherulites or crystalites, whereas some pitchstones (high water content) are entirely aphyric. Although the higher water content frequently gives pitchstone a tar-like lustre (thus its name), whereas obsidian generally has a highly vitreous lustre, it may be almost impossible to distinguish (on the basis of hand-samples) between the purest aphyric pitchstones (such as some of the material from the 'greater' Corriegills district on the Isle of Arran, Scotland; Ballin \& Faithfull 2009) and common obsidian (see Figure 1). As it is the impression of this author that there are more similarities than differences between pitchstone and obsidian, he has recently suggested that pitchstone ought to be perceived as a form of obsidian (Ballin 2014).

The main publication of the project Archaeological Pitchstone in Northern Britain (Ballin 2009a) dealt with a number of different issues relating to the procurement of pitchstone on the Isle of Arran - the location that has been proven, by petrological and geochemical analyses, to be the source of all archaeological pitchstone (Preston et al. 1998; 2002) - as well as the manufacture, distribution, use, and deposition of pitchstone artefacts throughouth northern Britain (Figure 2). One of the most interesting questions relating to prehistoric pitchstone use is arguably the procurement and exchange of this raw material and of pitchstone artefacts, and what this tells us about the nature of Neolithic society (Ballin 2008). However, for this discussion to take place, it was necessary to date archaeological pitchstone, both on the source island Arran, and at locations off this island. Any interpretation of a pitchstone exchange network would obviously be affected by the dates relating to artefacts in this raw material, that is, whether the exchange took place between more or less stratified societies.

When Williams Thorpe \& Thorpe (1984) presented their paper, the dating evidence was weak, and it was generally thought (and understandably so) that pitchstone might have been exchanged across northern Britain during most of Scottish prehistory, including the Mesolithic, Neolithic and Bronze Age periods. In 2009, after the recovery of much more archaeological pitchstone, it was possible to show that the exchange of this raw material, from Arran to the rest of northern Britain, probably mainly took place during the Early Neolithic period (two diagnostic chisel-shaped arrowheads from Biggar and Glenluce Sands indicate that this exchange may have ended around, or shortly after, the Early to Middle Neolithic transition; Ballin 2009a), although with some later use in Argyll \& Bute (which might have formed one part of a social territory in which Arran was also included) and Orkney in the far north (which in many respects represents a 'special case'; ibid.). Since 2009, a considerable amount of new dating evidence has come to light, and this has confirmed a Late Neolithic phase of pitchstone use and exchange along the western seaboard of Scotland and extending as far north as Orkney (Richards 2005). This appears to be part of a reciprocal movement of ideas, objects and people at that time - the use of Grooved Ware and timber and stone circles 
spreading south-westwards down the Atlantic façade and, among other things, pitchstone northwards along the same route (Sheridan 2004).
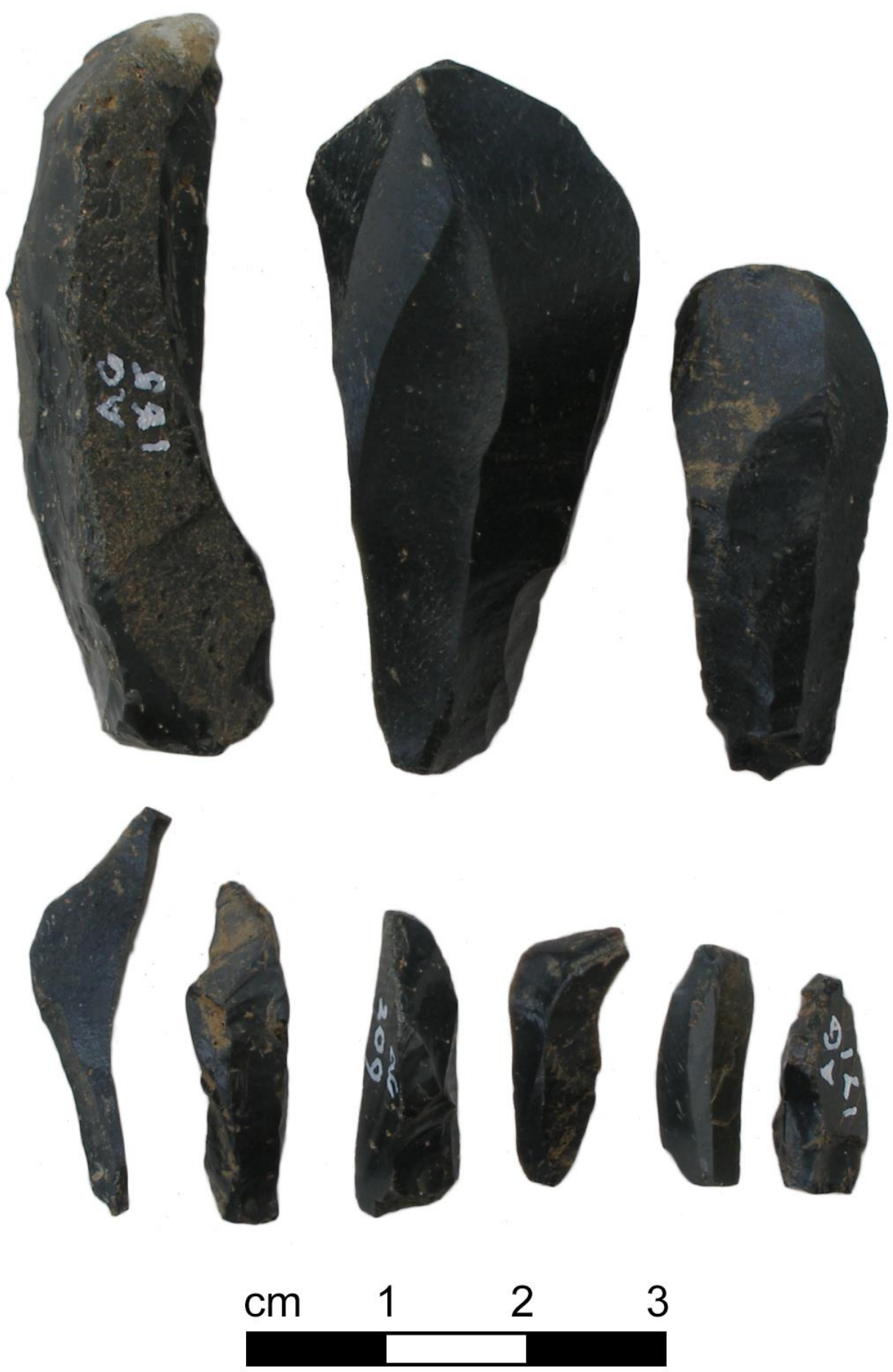

Figure 1. Pitchstone blades and microblades from Auchategan, Argyll \& Bute (Marshall 1978; Ballin 2006) (photo by Beverley Ballin Smith).

The purpose of the present paper is to present this new evidence, which generally relates to the recovery of pitchstone from pits, and which makes available a series of absolute radiocarbon dates. The archaeological pitchstone from pits is also dated indirectly through association with prehistoric pottery, and in addition this pitchstone provides supporting dates, 
through association in these same pits, for the importation into Scotland of axeheads of tuff (petrological Group VI) from Great Langdale in Cumbria (Bradley \& Edmonds 1993).

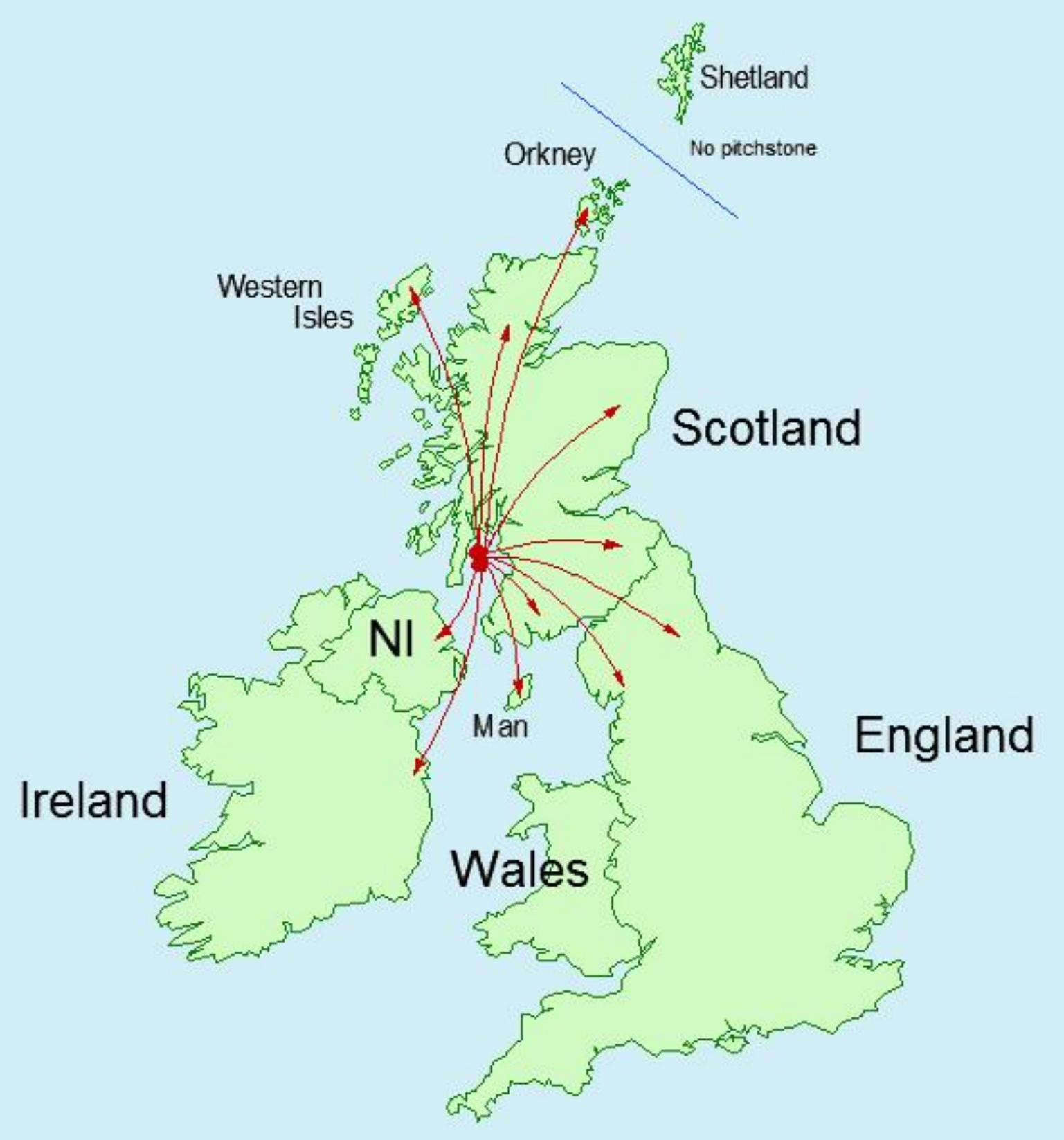

Figure 2. The distribution of archaeological pitchstone across northern Britain from the Isle of Arran in the Firth of Clyde, west of Glasgow. The only part of northern Britain where pitchstone artefacts have not been recovered is Shetland, where a marked insularity in the use of raw materials is evident (Ballin 2011c). The distance from Arran to Orkney is c. $400 \mathrm{~km}$. Pitchstone is expected - in due course of time - to be identified in assemblages further towards the south where it may have been misidentified as black chert, black flint, jet or glassy slag (Ballin 2008).

\section{General dating evidence}

The dating of archaeological pitchstone, as presented in Ballin (2009a), relies partly on positive evidence (the presence of diagnostic elements) and partly on negative evidence (the absence of diagnostic elements). The author fully accepts that absence of evidence is not necessarily evidence of absence, but when specific types, raw materials, technological 
attributes, etc. remain elusive in a large body of finds (such as the now numerous pieces of worked pitchstone recovered on the Scottish mainland) absence of for example certain implement forms may represent important circumstantial evidence.

On Arran itself, pitchstone was clearly used throughout the Mesolithic - Early Bronze Age period. The project The Early Settlement of Arran: the archaeology of the Water Ring Main, carried out by GUARD, University of Glasgow in 1999, showed that all diagnostic types usually associated with Mesolithic lithic assemblages are known from Arran, such as microliths and burins (pers. comm. John Atkinson, GUARD Archaeology Ltd.). Other diagnostic pitchstone artefacts have also been found on Arran, such as leaf-shaped, chiselshaped, oblique and barbed-and-tanged arrowheads (Haggarty 1991; Finlay 1997; and author's inspection of finds in Arran Museum).

The author's examination prior to 2009 of almost all archaeological pitchstone recovered on the Scottish mainland, and on other Scottish islands, showed that although most pitchstone blades are as narrow as those usually associated with Late Mesolithic assemblages (Figure 1, bottom row), the large number of available pitchstone artefacts from these parts of Scotland included no diagnostic Mesolithic types - not a single microlith was identified. Furthermore, the probable absence of pitchstone microliths on the Scottish mainland has recently been confirmed by the recovery of a large pitchstone assemblage at Stanton West, near Carlisle, which included microblades but no diagnostic Mesolithic types (Dickson forthcoming). Although, at Stanton West, the pitchstone artefacts were associated with a Mesolithic scatter, the context from which they were recovered was unsealed and as the site in general also includes diagnostic Neolithic material (Brown 2013) this association has little value in terms of safely dating the pitchstone artefacts.

However, leaf-shaped points - an Early Neolithic artefact type - are known off Arran, as are a small number of Middle Neolithic chisel-shaped arrowheads. This, and other supporting evidence, led the present author to suggest that, in general, the pitchstone exchange network on the Scottish mainland probably dates largely to the Early Neolithic, with the exchange slowly decreasing around the Early to Middle Neolithic transition, at the time when we see a massive increase in the importation of Yorkshire flint into Scotland from the opposite direction, as well as the introduction in Scotland of the innovative Levallois-like knapping technique (Ballin 2011a; 2011b).

\section{Pitchstone from radiocarbon-dated pits}

In 2009, only a small number of pitchstone artefacts were known from radiocarbon-dated pits, and several of these dates were characterized by quite large standard deviations, such as one from Carzield, and one from Chapelfield (Figure 3). Since then, numerous pits containing worked pitchstone have been excavated in Scotland. These are listed in Table 1.

It is obvious from Figure 3 that deposition of pitchstone in pits, and thereby the exchange of pitchstone between Arran and the rest of Britain, is predominantly an Early Neolithic phenomenon, as also suggested by other evidence (above). Although some of the pitchstone in the pits is in the form of flakes, several pieces are microblades or very narrow macroblades (in Scotland, as well as in Norway, blades tend to be generally narrower than those of other parts of Europe, for which reason consensus in Scotland and Norway is to distinguish between microblades and broad blades as pieces narrower and broader than $8 \mathrm{~mm}$ [Ballin 1996; 2000]; this is essential in terms of distinguishing between the microblade and broad blades industries of Norway and Scotland). Most of the pits also contained other lithics, either flint, chert or quartz, and a flint artefact from Pit 7 (which contained the site's pitchstone) 
underneath Fordhouse Barrow was identified as an Early Neolithic leaf-shaped point. As many as 12 out of the 14 pits contained Early Neolithic pottery of the Carinated Bowl tradition, in either its 'traditional' or 'modified' versions (See Sheridan 2007 for a definition of these terms). Four pits contained one or more flakes struck off Group VI axeheads; and four pits contained burnt bone, with the bone from two of these having been identified as human (Maybole).

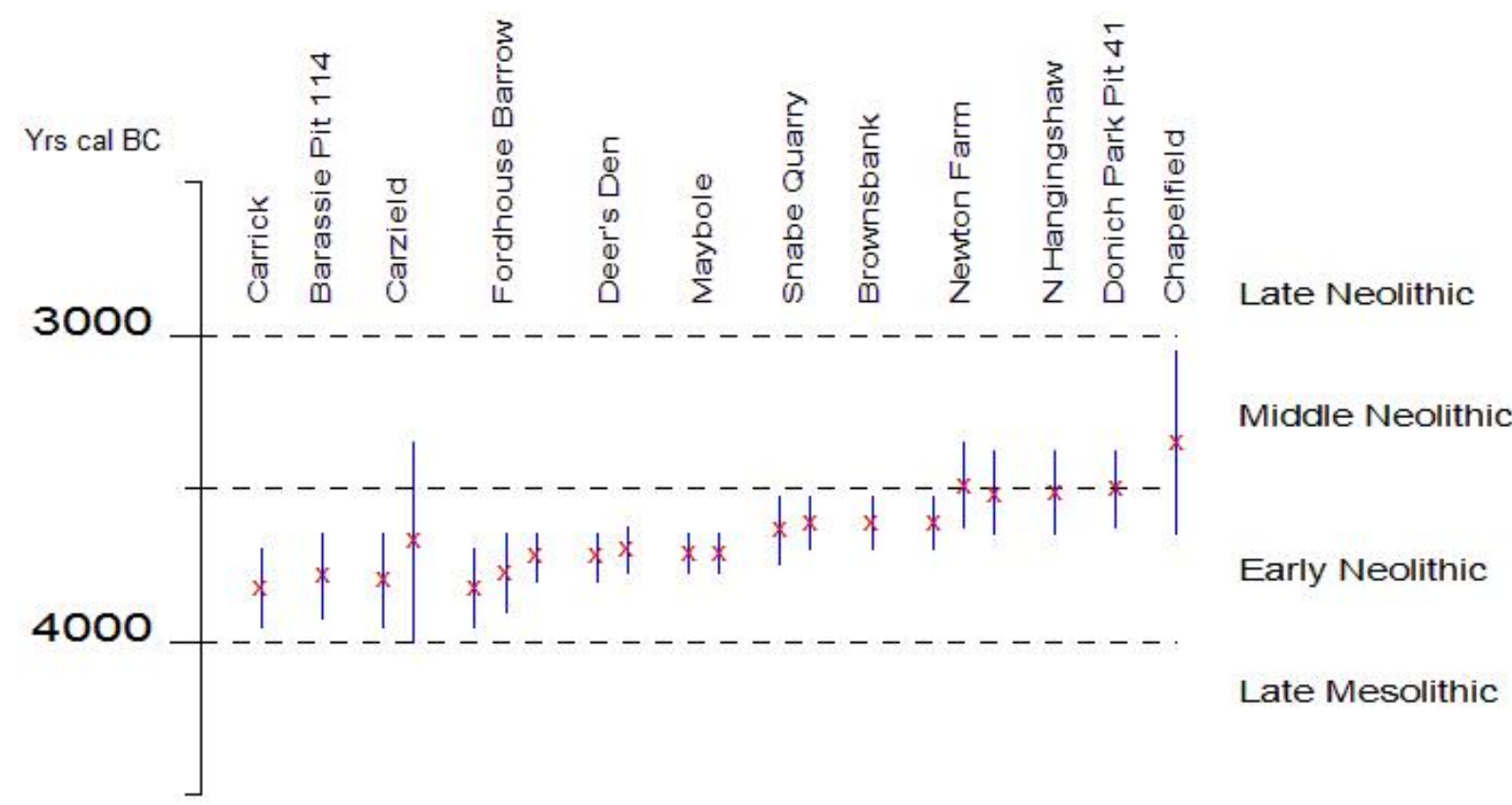

Figure 3. Radiocarbon dates relating to pitchstone-bearing pits (site names along the top of the diagram). Note that the dates from Fordhouse Barrow are TAQ dates provided by charcoal recovered immediately above the pitchstone-bearing pit; a leaf-shaped point from this pit defines the deposition as EN, and the pitchstone from the Fordhouse Barrow pit therefore clearly dates to the first half of the Early Neolithic.

The pit underneath Fordhouse Barrow has not been dated by charcoal from the pit itself, but the leaf-shaped flint point associated with the pit's pitchstone defines the small assemblage as definitely post-Mesolithic, and the three listed radiocarbon dates (Table 1) are from the barrow's Phase 3B immediately above the pit, thus providing TAQ dates for the pit.

In addition to the radiocarbon-dated pitchstone listed in Table 1, pitchstone has also been indirectly dated by association with Early Neolithic pottery of the Carinated Bowl tradition. Three pitchstone blades or microblades were recovered from three pits at the Elginhaugh Roman Fort (Midlothian), all containing this kind of Early Neolithic pottery (note that in the Elginhaugh publication, the lithics report dates these blades to the Late Neolithic or Early Bronze Age, although the same volume's pottery report clearly identifies the pottery from the pits as belonging to the Carinated Bowl tradition: Clarke 2007; MacGregor 2007). From a pit at the Roman Fort Bishopton, Whitemoss (Renfrewshire), two pitchstone 'chips' were recovered, also associated with pottery of this tradition, as is clear from Piggott's description:

'Beneath the Roman Fort, Professor Piggott found eight shallow oval or circular pits containing black greasy soil, a flint leaf-shaped arrowhead and a scraper, two chips of Arran pitchstone, and pottery of the type found at Bantaskine, Easterton of Roseisle and Lyles Hill, Belfast' (Trump 1956, 218).

Furthermore, a small collection of worked pitchstone was recovered from what is now perceived to be an Early Neolithic timber hall - the greater of the two halls at Doon Hill, East 
Lothian (Ballin 2009b; Brophy \& Sheridan 2012, 62). A 10mm wide pitchstone blade was recovered from one of two twin roof-bearing posts in the central part of the hall, with another five pieces of burnt pitchstone deriving from two southern wall posts. In addition, a $12 \mathrm{~mm}$ wide blade was recovered from a posthole in the hall's north-eastern corner. Moreover, the pitchstone was associated with a leaf-shaped arrowhead of flint, recovered from a posthole in the hall's northern long-side, as well as pottery of the Carinated Bowl tradition.

\section{Conclusion}

In general terms, the evidence provided by the pitchstone artefacts from radiocarbondated pits, and the common association of the worked pitchstone with pottery of the Carinated Bowl tradition, strengthens the date of archaeological pitchstone suggested in Ballin (2009a), that is, that the exchange of pitchstone from Arran and across northern Britain was predominantly an Early Neolithic phenomenon (apart from the aforementioned later exchange route along the Atlantic seaboard) which slowed down and finally fell apart as a new exchange system, and perhaps a new form of social organization, was born, that of Yorkshire flint (Ballin 2011b).

\section{Acknowledgements}

I would like to thank Alison Sheridan, Principal Curator, Early Prehistory, National Museums Scotland, for taking the time to comment and advice on this paper. I would also like to thank John Atkinson, Maureen Kilpatrick and Iraia Arabaolaza, GUARD Archaeology Ltd., Gill Hey, Antony Dickson, and Fraser Brown, Oxford North, as well as Clare Ellis, Argyll Archaeology, for permission to mention unpublished results from their excavations. I am grateful to two anonymous referees for their constructive comments on the draft manuscript.

\section{References}

Alexander, D. 2000, Excavations of Neolithic pits, later prehistoric structures and a Roman temporary camp along the line of the A96 Kintore and Blackburn Bypass, Aberdeenshire. Proceedings of the Society of Antiquaries of Scotland, 130: 11-75. URL: http://archaeologydataservice.ac.uk/archiveDS/archiveDownload?t=arch-3521/dissemination/pdf/vol_130/130_011_075.pdf

Atkinson, J. 2002, Excavation of a Neolithic occupation site at Chapelfield, Cowie, Stirling. Proceedings of the Society of Antiquaries of Scotland, 132: 139-192. URL: http://archaeologydataservice.ac.uk/archiveDS/archiveDownload?t=arch-3521/dissemination/pdf/vol_132/132_139_192.pdf

Ballin, T.B. 1996, Klassifikationssystem for stenartefakter. Varia Vol. 36. Universitetets oldsaksamling, Oslo, 83 p. (in Norwegian) ("Classification of Lithic and Stone Artefacts")

Ballin, T.B. 2000, Classification and description of lithic artefacts. A discussion of the basic lithic terminology. Lithics, 21: 9-15. URL: https://dl.dropboxusercontent.com/u/14836110/LithicsPDFs/Lithics\%2021/lithics_21_2 000_Bal_9-15.pdf 
Ballin, T.B. 2006, Re-examination of the Early Neolithic pitchstone-bearing assemblage from Auchategan, Argyll, Scotland. Lithics, 27: 12-32. URL: http://www.southampton.ac.uk/ drus105/LithicsPDFs/Lithics\%2027/Lithics_27_2006_ Ballin_12_32.pdf

Ballin, T.B. 2008, The distribution of Arran pitchstone: territories, exchange and the 'English problem'. PAST, 60: 10-13. URL: http://www.le.ac.uk/has/ps/past/past060.pdf

Ballin, T.B. 2009a, Archaeological pitchstone in northern Britain : characterization and interpretation of an important prehistoric source. BAR British series Vol. 476. Archaeopress, Oxford, 108 p. (in English)

Ballin, T.B. 2009b, The lithic assemblage from Doon Hill, Dunbar, East Lothian. Unpublished report

Ballin, T.B. 2011a, The Levallois-like approach of Late Neolithic Britain: a discussion based on finds from the Stoneyhill Project, Aberdeenshire. In: Flint and stone in the neolithic period (Saville, A., Ed.) Neolithic Studies Group seminar papers Vol. 11, Oxbow Books, Oxford: p. 37-61.

Ballin, T.B. 2011b, Overhowden and Airhouse, Scottish Borders : characterization and interpretation of two spectacular lithic assemblages from sites near the Overhowden henge. BAR British series Vol. 539. Archaeopress, Oxford, 74 p.

Ballin, T.B. 2011c, The post-glacial colonization of Shetland - integration or isolation? Evidence from lithic and stone assemblages. In: Farming on the edge - cultural landscapes of the North: some features of the Neolithic of Shetland: short papers from the network meeting in Lerwick, Shetland, September 7th-10th 2010 (Mahler, D.L. \& Andersen, C., Eds.), National Museum of Denmark, Copenhagen: p. 32-43.

Ballin, T.B. 2014, Pitchstone: The poor cousin of obsidian? IAOS (International Association for Obsidian Studies) Bulletin, 52: 14-17. URL: http://members.peak.org/ obsidian/iaos_bulletin_52.pdf

Ballin, T.B. \& Faithfull, J. 2009, Gazetteer of Arran Pitchstone Sources. Presentation of exposed pitchstone dykes and sills across the Isle of Arran, and discussion of the possible archaeological relevance of these outcrops. Scottish Archaeological Internet Reports Vol. 38 p. 39 URL: http://archaeologydataservice.ac.uk/archives/view/sair/contents.cfm?vol=38

Becket, A. \& MacGregor, G. 2012, Big pit, little pit, big pit, little pit ...: pit practices in western Scotland in the 4th millennium BC. In: Regional perspectives on Neolithic pit deposition : beyond the mundane (Anderson-Whymark, H. \& Thomas, J., Eds.) Neolithic Studies Group seminar papers Vol. 12, Oxbow Books, Oxford: p. 51-62.

Becket, A., MacGregor, G., Clarke, A., Duffy, P., Finlay, N., Miller, J. \& Sheridan, A. 2009, Forest grazing and seaweed foddering: early Neolithic occupation at Maybole, South Ayrshire. Proceedings of the Society of Antiquaries of Scotland, 139: 105-122. URL: http://archaeologydataservice.ac.uk/archiveDS/archiveDownload?t=arch-3521/dissemination/pdf/vol_139/139_105_122.pdf

Bradley, R. \& Edmonds, M.R. 1993, Interpreting the axe trade : production and exchange in Neolithic Britain. New studies in archaeology. Cambridge University Press, Cambridge, $236 \mathrm{p}$. 
Brophy, K. \& Sheridan, A., (Eds) 2012, Neolithic Scotland. ScARF Panel Report. ScARF Summary Neolithic Panel Document. Scottish Archaeological Research Framework, Edinburgh, 147 p.

Brown, F. 2013, A brief discussion of the prehistoric finds from Stainton West, Carlisle, Cumbria. IfA Finds Group newsletter, Autumn 2013: 4-11. URL: http://www.archaeologists.net/sites/default/files/node-files/Autumn-2013-IfA-FindsGroup-newsletter-V2.pdf

CANMORE 2014, The CANMORE online database. Retrieved 24 DEC 2014. URL: http://canmore.rcahms.gov.uk

Clarke, A. 2007, The flaked lithic assemblage. In: Elginhaugh : a Flavian fort and its annexe (Hanson, W.S., Speller, K., Yeoman, P.A. \& Terry, J., Eds.) Britannia monograph series Vol. 23, Society for the Promotion of Roman Studies, London: p. 537-565.

Dickson, A. (in press), The Pitchstone. In: The archaeology of the Carlisle Northern Development Route (Brown, F., Dickson, A., Clark, P., Gregory, R. \& Zant, J., Eds.), Lancaster Imprints, Lancaster.

Finlay, N. 1997, Various entries. In: The Archaeological investigation of a prehistoric landscape : excavations on Arran 1978-1981 (Barber, J., Ed.) STAR Monograph Vol. 2, Scottish Trust for Archaeological Research, Edinburgh.

Haggarty, A., Henshall, A., Grove, R., Cowie, T., Foyon, A., McCullagh, R., Jordan, D., Moffat, B. \& Lehane-Magee, D. 1991, Machrie Moor, Arran: recent excavations at two stone circles. Proceedings of the Society of Antiquaries of Scotland, 121: 51-94. URL: $\mathrm{http} / / /$ archaeologydataservice.ac.uk/archiveDS/archiveDownload?t=arch-3521/dissemination/pdf/vol_121/121_051_094.pdf

Le Maitre, R.W., (Ed), 2002, Igneous rocks a classification and glossary of terms : recommendations of the International Union of Geological Sciences, Subcommission on the Systematics of Igneous Rocks, (2nd ed.). Cambridge University Press, Cambridge, $236 \mathrm{p}$.

MacGregor, G. 2007, Prehistoric pottery. In: Elginhaugh : a Flavian fort and its annexe (Hanson, W.S., Speller, K., Yeoman, P.A. \& Terry, J., Eds.) Britannia monograph series Vol. 23, Society for the Promotion of Roman Studies, London: p. 515-536.

Marshall, D.N. 1978, Excavations at Auchategan, Glendaruel, Argyll. Proceedings of the Society of Antiquaries of Scotland, 109: 36-74. URL:

http://archaeologydataservice.ac.uk/archiveDS/archiveDownload?t=arch-3521/dissemination/pdf/vol_109/109_036_074.pdf

Maynard, D. 1993, Neolithic pit at Carzield, Kirkton, Dumfriesshire. Transactions of the Dumfriesshire \& Galloway Natural History \& Antiquarian Society, 68: 25-32. URL: http://www.dgnhas.org.uk/transonline/SerIII-Vol68.pdf\#page=30

O'Brien, L., Clements, V., Roy, M. \& Macnab, N. 2009, Neolithic Pits, a Bronze Age Cremation and an Early Iron Age Ring-Ditch at Newton Farm, Cambuslang, Lanarkshire. Scottish Archaeological Journal, 31(1-2): 1-31. doi:10.3366/saj.2010.0002

Pellant, C. 1992, Rocks and minerals: The visual guide to over 500 rock and mineral specimens from around the world. Eyewitness handbooks Vol. 1. Dorling Kindersley, London, $256 \mathrm{p}$. 
Preston, J., Meighan, I., Simpson, D. \& Hole, M. 2002, Mineral chemical provenance of Neolithic pitchstone artefacts from Ballygalley, County Antrim, Northern Ireland. Geoarchaeology, 17(3): 219-236. doi:10.1002/gea.10011

Preston, R.J., Hole, M.J., Still, J. \& Patton, H. 1998, The mineral chemistry and petrology of Tertiary pitchstones from Scotland. Transactions of the Royal Society of Edinburgh: Earth Sciences, 89(2): 95-111. doi:10.1017/S0263593300007033

Richards, C., (Ed), 2005, Dwelling among the monuments : the Neolithic village of Barnhouse, Maeshowe passage grave and surrounding monuments at Stenness, Orkney, McDonald Institute monographs. McDonald Institute for Archaeological Research, Cambridge, 397 p.

Sheridan, A. 2007, From Picardie to Pickering and Pencraig Hill? New information on the 'Carinated Bowl Neolithic' in northern Britain. Proceedings of the British Academy, 144: 441-492. doi:10.5871/bacad/9780197264140.003.0023

Sheridan, J.A. 2004, Going round in circles? Understanding the Irish Grooved Ware 'complex' in its wider context. In: From megaliths to metal : essays in honour of George Eogan (Roche, H., Grogan, E., Bradley, J., Coles, J. \& Raftery, B., Eds.), Oxbow Books, Oxford: p. 26-37.

Trump, D. 1958, Notes on Excavations in Eire, England, Northern Ireland, Scotland and Wales, during 1956. Proceedings of the Prehistoric Society (New Series), 23: 220-230. doi: $10.1017 / \mathrm{s} 0079497 \times 00017011$

Ward, T. 2014, Biggar Archaeology Group List of radiocarbon dates. URL: http://www.biggararchaeology.org.uk/pdf_reports/BAG_RadiocarbonDates.pdf

Williams-Thorpe, O. \& Thorpe, R.S. 1984, The distribution and sources of archaeological pitchstone in Britain. Journal of Archaeological Science, 11(1): 1-34.

doi:10.1016/0305-4403(84)90039-6 
Table 1. Radiocarbon-dated pits containing worked pitchstone, plus details of the radiocarbon dates that provide a taq for pitchstone use at Fordhouse Barrow.

\begin{tabular}{|c|c|c|c|c|c|c|c|c|c|c|}
\hline CAT & Site & $\begin{array}{l}\text { Local } \\
\text { authority } \\
\text { areas } \\
\end{array}$ & Ref. & Context & Code & $\begin{array}{l}\text { Lab date } \\
\text { BP }\end{array}$ & $\begin{array}{c}\text { cal BC, } \\
95.4 \% \\
\text { probability } \\
\end{array}$ & $\begin{array}{c}\text { Carinated } \\
\text { Bowl } \\
\text { pottery } \\
\end{array}$ & $\underset{\text { VI }}{\text { Group }}$ & $\begin{array}{l}\text { Full assemblage (CB = } \\
\text { Carinated Bowl) }\end{array}$ \\
\hline 1 & Carzield & Dumf \& Gall & Maynard 1993 & Pit & Beta- 68480 & $5010 \pm 70$ & $3960-3660$ & \multirow[b]{2}{*}{$x$} & \multirow[b]{2}{*}{$x$} & \multirow{2}{*}{$\begin{array}{l}2 \text { pitchstone microblades, } 3 \\
\text { flint flakes, } 3 \text { flakes from Group } \\
\text { VI axehead; CB pottery }\end{array}$} \\
\hline 2 & & & do & Pit & Beta-68481 & $4920 \pm 110$ & $4000-3350$ & & & \\
\hline 3 & Deer's Den & $\begin{array}{c}\text { Aberdeenshir } \\
\mathrm{e}\end{array}$ & Alexander 2000 & Pit 1028 & OxA-8132 & $4945 \pm 40$ & $3800--3640$ & \multirow{2}{*}{$x$} & & \multirow{2}{*}{$\begin{array}{l}1 \text { pitchstone flake, } 61 \text { lithics, } \\
64 \% \text { of which flint, } 36 \% \text { quartz, } \\
1 \text { leaf-shaped point in flint; CB } \\
\text { pottery }\end{array}$} \\
\hline 4 & & & do & Pit 1028 & OxA-8133 & $4895 \pm 40$ & $3770-3630$ & & & \\
\hline 5 & $\begin{array}{l}\text { Nether } \\
\text { Hanginshaw }\end{array}$ & S Lanarkshire & Ward 2014 & Pit F20 & GU-12113 & $4780 \pm 40$ & $3650-3380$ & $x$ & $x$ & $\begin{array}{l}1 \text { pitchstone flake, } 13 \text { chert } \\
\text { flakes, } 1 \text { flake from a Group VI } \\
\text { axehead; } 1 \text { piece of burnt } \\
\text { bone; CB pottery }\end{array}$ \\
\hline 6 & Brownsbank & S Lanarkshire & Ward 2014 & Pit F2 & GU-9303 & $4865 \pm 45$ & $3709-3538$ & $x$ & & $\begin{array}{l}1 \text { microblade and } 1 \text { flake in } \\
\text { pitchstone, } 4 \text { chert flakes, } 1 \\
\text { flake of 'siltstone', burnt bone, } \\
\text { and CB pottery }\end{array}$ \\
\hline 7 & Chapelfield & Stirling & Atkinson 2002 & Pit VIII & GU-7202 & $4640 \pm 90$ & $3650--3050$ & $x$ & & $\begin{array}{l}4 \text { pitchstone microblades, } \\
\text { some coarse stone tools; } C B \\
\text { pottery }\end{array}$ \\
\hline 8 & $\begin{array}{l}\text { Fordhouse } \\
\text { Barrow }\end{array}$ & Angus & CANMORE 2014 & $\begin{array}{l}\text { Barrow's } \\
\text { Phase 3B }\end{array}$ & OxA-8222 & $5035 \pm 40$ & $3960--3710$ & & & \multirow{3}{*}{$\begin{array}{l}7 \text { pitchstone microblades, } 3 \\
\text { pitchstone flakes; } 1 \text { burnt leaf- } \\
\text { shaped point in flint, } 1 \text { chert } \\
\text { chunk [provide TAQ dates for } \\
\text { pitchstone in C507 (Pit 7) } \\
\text { beneath Ph. 3B] }\end{array}$} \\
\hline 9 & & & CANMORE 2104 & $\begin{array}{l}\text { Barrow's } \\
\text { Phase 3B }\end{array}$ & OxA-8223 & $4920 \pm 45$ & $3790--3640$ & & & \\
\hline 10 & & & CANMORE 2014 & $\begin{array}{l}\text { Barrow's } \\
\text { Phase 3B }\end{array}$ & OxA-8224 & $4965 \pm 40$ & 3910-3650 & & & \\
\hline 11 & Donich Park & Argyll \& Bute & $\begin{array}{l}\text { Clare Ellis pers. } \\
\text { comm. }\end{array}$ & Pit 41 & GU-29791 & $4714 \pm 33$ & $3632--3376$ & & & 2 pitchstone flakes \\
\hline 12 & $\begin{array}{l}\text { Snabe } \\
\text { Quarry }\end{array}$ & S Ayrshire & $\begin{array}{l}\text { Maureen } \\
\text { Kilpatrick pers. } \\
\text { comm. }\end{array}$ & Pit 22 & GU-32479 & $4872 \pm 42$ & $3763--3535$ & \multirow[t]{2}{*}{$x$} & \multirow[t]{2}{*}{$x$} & \multirow{2}{*}{$\begin{array}{l}1 \text { pitchstone flake, } 5 \text { flint chips, } \\
2 \text { flint microblades, } 1 \text { edge- } \\
\text { retouched flake from a Group } \\
\text { VI polished stone axehead; } \\
\text { sherds of CB pottery }\end{array}$} \\
\hline 13 & & & do & Pit 22 & GU-32480 & $4820 \pm 42$ & $3695--3520$ & & & \\
\hline
\end{tabular}




\begin{tabular}{|c|c|c|c|c|c|c|c|c|c|c|}
\hline CAT & Site & $\begin{array}{l}\text { Local } \\
\text { authority } \\
\text { areas }\end{array}$ & Ref. & Context & Code & $\begin{array}{l}\text { Lab date } \\
\qquad \text { BP }\end{array}$ & $\begin{array}{c}\text { cal BC, } \\
95.4 \% \\
\text { probability }\end{array}$ & $\begin{array}{c}\text { Carinated } \\
\text { Bowl } \\
\text { pottery }\end{array}$ & $\begin{array}{c}\text { Group } \\
\text { VI }\end{array}$ & $\begin{array}{l}\text { Full assemblage (CB = } \\
\text { Carinated Bowl) }\end{array}$ \\
\hline 14 & Maybole & S Ayrshire & $\begin{array}{c}\text { Becket \& } \\
\text { MacGregor } 2009\end{array}$ & Pit 10 & GU-16716 & $4939 \pm 30$ & $3780-3650$ & $x$ & & $\begin{array}{l}30 \text { flaked lithics, mostly flint } \\
\text { but also pitchstone; CB } \\
\text { pottery; burnt human bone }\end{array}$ \\
\hline 15 & & & do & Pit 18 & GU-16715 & $4940 \pm 40$ & $3780--3650$ & $x$ & $x$ & $\begin{array}{l}14 \text { flaked lithics, mostly flint ( } 2 \\
\text { of which scrapers) but also } 3 \\
\text { pieces of pitchstone, } 1 \text { inner } \\
\text { flake from Group VI axehead; } \\
\text { CB pottery; burnt human bone }\end{array}$ \\
\hline 16 & The Carrick & Argyll \& Bute & $\begin{array}{c}\text { Becket \& } \\
\text { MacGregor } 2012\end{array}$ & $\begin{array}{c}\text { Pit } \\
0510573\end{array}$ & $\begin{array}{l}\text { SUERC- } \\
19349\end{array}$ & & $3950--3700$ & $x$ & & 1 pitchstone flake; CB pottery) \\
\hline 17 & $\begin{array}{l}\text { Newton } \\
\text { Farm }\end{array}$ & S Lanarkshire & O'Brien 2009 & Pit 104 & GU-17330 & $4835 \pm 35$ & $3700--3520$ & $x$ & & $\begin{array}{l}2 \text { pitchstone flakes and various } \\
\text { other lithics; CB pottery }\end{array}$ \\
\hline 18 & & & do & Pit 110 & GU-17331 & $4685 \pm 35$ & $3630--3360$ & $x$ & & $\begin{array}{l}\text { Various lithics, including } \\
\text { aphyric pitchstone; CB pottery }\end{array}$ \\
\hline 19 & & & do & Pit 102 & GU-17329 & $4710 \pm 35$ & $3640--3370$ & $x$ & & $\begin{array}{l}1 \text { pitchstone blade, } 1 \text { burnt } \\
\text { flint flake; CB pottery }\end{array}$ \\
\hline 20 & Barassie & S Ayrshire & Iraia Arabaolaza & Pit 114 & GU-35500 & $4966 \pm 39$ & $3915-3653$ & & & 9 chips of flint or quartz \\
\hline
\end{tabular}

